\title{
LinkedIn For Accounting And Business Students
}

\author{
W. David Albrecht, Concordia College, USA
}

\begin{abstract}
LinkedIn is a social media application that every accounting and business student should join and use. LinkedIn is a database of 90,000,000 business professionals that enables each to connect and interact with their business associates.
\end{abstract}

Five reasons are offered for why accounting students should join LinkedIn followed by 11 hints for use.

Keywords: LinkedIn; Social Media; Accountant use of Social Media

\section{INTRODUCTION}

e are in the social media century. It is likely that some social media application has significantly
impacted your life. Facebook has over 500 million active users, with average usage at 47 minutes
each day (Facebook, 2011). YouTube has resulted in a new phrase added to our daily vocabularygoing viral. A social media app or application has made it big when it becomes a verb - friended, tweeted, skyped, texted, blogged.

Social media has had a profound impact on business (Golden, 2010). Accounting firms are abandoning traditional marketing channels and are moving to social media for getting the word out (Golden, 2010; MACPA, 2010). Competency in social media is becoming as important to your career as mastery of debits and credits.

LinkedIn is a social media application that is essential for any business professional. It has been said that everyone in business should be on it (Schaffer, 2009); many are. The most used social media app is LinkedIn (Association of Accounting Marketing, 2010). The purpose of this article is to explain why you-an accounting and business student-should be on LinkedIn and how you should use it.

\section{WHAT IS LINKEDIN}

LinkedIn is a mainstream business application with several important capabilities. First, it is a large database of business professionals with 90 million members as of January 2011. Each user has a record that contains 1) biographical information - called a profile, 2) a list of business associates also on LinkedIn, and 3) contact information. Second, it is a social network. A social network brings together people who have relationships and who potentially could have relationships. This is accomplished, in large part, through the key word search function. Third, LinkedIn provides convenient channels of communication, allowing its members to interact and share. This is accomplished by 1) the feature of sending e-mails through LinkedIn to members of your network and 2) discussion groups organized around specialized topics.

LinkedIn offers free basic accounts, which are adequate for most users. It also offers paid subscriptions. Paid subscriptions return a higher number of search results and permit sending e-mails (or inmails) to members not a part of your network. "LinkedIn paid accounts are generally geared toward professionals, such as HR representatives and recruiters ..." (Burnham, 2010). 


\section{WHY JOIN AND USE LINKEDIN}

Students are extremely busy. There is too much to do and too little time to do it. Prioritization is a must. Joining and using LinkedIn is as important as creating a resume or taking Intermediate Accounting, and should be done just as early in your collegiate experience. Here are five reasons why you should do it now:

1. LinkedIn is a mainline business tool. There are 90 million users on LinkedIn, most of whom are in the business world. They use it, and expect you to be on it. Please don't disappoint.

2. LinkedIn is how $21^{\text {st }}$ century professionals build and manage their network of business associates. The business world is a team sport where you and your network compete against others. Your network is comprised of people who like, admire, and respect you. They have worked with you in the past and they are willing to work with you in the future. The foundation of your network is the group of students with whom you study, take classes and enjoy life. You need to formally connect with them before they leave campus.

3. LinkedIn is where you professionally present yourself to the business world. It gives you the flexibility to manage your image (or brand). This is done through your LinkedIn profile, which serves as a searchable resume. When others Google you, it will probably be the first item on the list. On your way to an interview? Check out the profile of the interviewer.

4. LinkedIn makes it convenient to stay in touch and informed about the members of your network. It isn't true that you will always know a contact's e-mail or phone number. Each time a business person changes positions or moves around, their phone number and e-mail address can change. If they regularly update their profile, you will always have the latest contact information.

5. LinkedIn will be very useful to you after college when you are out in the business world. It will help your career. In the same way that farmers plant seeds months before anyone eats the food, you will need to create, grow and develop your LinkedIn profile and network before there is a direct need of it. An important future use will be to search your extended network (your contacts have contacts who in turn have contacts).

Many professionals use LinkedIn to find a job. Although it might serve that function after you have been out of school for a while, it probably won't help you land that first job after college.

\section{TIPS FOR USING LINKEDIN}

Once a student has signed up for a free basic account at www.linkedin.com, the fun can begin. Here are ways to take advantage of LinkedIn's many features.

1. Create a comprehensive profile. Make it visible to everyone. You are making no personal revelations here, only providing information that is available on your resume. You have already sent those out by the hundreds, haven't you?

2. Invite your college professors to connect and join your network. Not all of your professors are on Linkedin, but some undoubtedly are. Most professors will be eager for the chance to stay connected with you after graduation.

3. Ask your professors to write a Linkedin recommendation for you. The value of a positive recommendation should be obvious.

4. Invite your fellow students to connect and join your network. They are your friends now and can be your friends for a long time if you nurture the relationship. More than friends, they form the core of your professional network. Years after college, they can be helpful with business referrals and help in locating new positions.

5. Make Linkedin the home page on your browser. Viewing your network activity makes you aware of what people in your network are doing. You should check it every day.

6. Because LinkedIn is the hub of where you professionally present yourself to the world, put your profile URL on your resume and business cards. If you have a blog, add a link to your profile. Also, update your profile URL to your name, if possible (the author's is http://www.linkedin.com/in/profalbrecht). 
7. Because social interaction is the means through which you will strengthen your existing network and grow it in the future, get started by joining LinkedIn discussion groups related to your major and your school. Every college's business school should have its own group. Occasionally post a question or an update.

8. Always remember that LinkedIn is not Facebook. You should not post personal photos, nor engage in unprofessional conversations. Remember, no one wants to know what you ate for breakfast or what you did on Saturday night. They are interested if you are looking for a new position, recently found a new one, or acquired an important competency. Business people are busy and will disconnect you if you send out too many or too frivolous status updates.

9. Include a professional photograph (i.e., business suit).

10. Always keep your e-mail and phone number current. Remember to change these after graduation.

11. Send a personal note to anyone joining your network. Saying thank you has never gone out of style.

\section{CONCLUSION}

Business professors find LinkedIn to be extremely useful, and so will you. They use LinkedIn to get reacquainted with former friends, associates and former students, sending out an occasional personal note to a few members of their network. In addition, they connect with consulting clients, directors and staff of state CPA societies, professionals at the FASB and PCAOB. Professors make these connections because it is easy to have directed communication through LinkedIn. Not only do professors need to send notes to, they also receive communications from textbook authors, journalists, professionals and form students through LinkedIn.

You should begin and continue to use LinkedIn. It is sure to be a value-added tool for your professional career.

\section{AUTHOR INFORMATION}

David Albrecht is an Associate Professor of Accounting at Concordia College, where he teaches various courses in financial accounting. He has a blog, The Summa (http://profalbrecht.wordpress.com), where he provides a professor's perspective to accounting and auditing issues. He also actively uses Twitter (@profalbrecht) and LinkedIn groups. E-mail: albrecht@profalbrecht.com

\section{REFERENCES}

1. Association of Accounting Marketing (2010). Association for Accounting Marketing Social Media Survey, August 2010. Retrieved February 23, 2011, from http://www.accountingmarketing.org/pdfs/2010/08162010_social_media_survey_results.pdf

2. $\quad$ Burnham, Kristin. (2010). “LinkedIn Quick Tip: Should You Upgrade to a Paid Account?”, CIO.com. Retrieved February 24, 2011, from http://www.cio.com/article/528663/LinkedIn_Quick_Tip_Should_You_Upgrade_to_a_Paid_Account

3. $\quad$ Facebook. (2011). "Pressroom.” Retrieved February 21, 2011, from http://www.facebook.com/press/info.php?statistics

4. Golden, Michelle. (2010). Social Media: Strategies for Professionals and Their Firms. John Wiley and Sons, Hoboken, New Jersey.

5. MACPA. (2010). "Survey: Most CPA firms now using social media." Retrieved February 23, 2011, from http://www.macpa.org/Content/25921.aspx

6. $\quad$ Schaffer, Neal. (2009). Understanding, Leveraging \& Maximizing LinkedIn. Self published by Neal Schaffer via Booksurge. 


\section{NOTES}

